University of South Florida

DIGITAL COMMONS

Digital Commons @ University of

@ UNIVERSITY OF SOUTH FLORIDA

South Florida

$11-10-2006$

\title{
Coral-Based Climate Variability in the Western Pacific Warm Pool since 1867
}

Terrence M. Quinn

University of South Florida, quinn@marine.usf.edu

Frederick W. Taylor

University of Texas

Thomas J. Crowley

Duke University

Follow this and additional works at: https://digitalcommons.usf.edu/msc_facpub

Part of the Marine Biology Commons

\section{Scholar Commons Citation}

Quinn, Terrence M.; Taylor, Frederick W.; and Crowley, Thomas J., "Coral-Based Climate Variability in the Western Pacific Warm Pool since 1867" (2006). Marine Science Faculty Publications. 82.

https://digitalcommons.usf.edu/msc_facpub/82

This Article is brought to you for free and open access by the College of Marine Science at Digital Commons @ University of South Florida. It has been accepted for inclusion in Marine Science Faculty Publications by an authorized administrator of Digital Commons @ University of South Florida. For more information, please contact digitalcommons@usf.edu. 


\title{
Coral-based climate variability in the Western Pacific Warm Pool since 1867
}

\author{
Terrence M. Quinn, ${ }^{1}$ Frederick W. Taylor, ${ }^{2}$ and Thomas J. Crowley ${ }^{3}$ \\ Received 23 August 2005; revised 19 May 2006; accepted 21 July 2006; published 10 November 2006.
}

[1] We have generated monthly resolved, stable isotope $\left(\delta^{18} \mathrm{O}\right.$ and $\left.\delta^{13} \mathrm{C}\right)$ and $\mathrm{Sr} / \mathrm{Ca}$ time series from a massive Porites coral from Rabaul $\left(4^{\circ} \mathrm{S}, 152^{\circ} \mathrm{E}\right)$ : a site located in the warmest sector of the Western Pacific Warm Pool (WPWP). The coral $\delta^{18} \mathrm{O}$ and $\mathrm{Sr} / \mathrm{Ca}$ time series are well correlated to each other and positive excursions in both records coincide with times of ENSO warm phase events. These time series contain abundant interannual variability that exhibits the well-recognized pattern of low amplitude ENSO variation between $\sim 1920-1960$ and high amplitude ENSO variation between 1880-1920 and 1960-1997. The ENSO-filtered coral $\delta^{18} \mathrm{O}$ and $\mathrm{Sr} / \mathrm{Ca}$ time series are well matched to each other $(\mathrm{r}=0.73)$ and to similarly filtered coral $\delta^{18} \mathrm{O}$ records from Papua New Guinea $(\mathrm{r}>0.56)$. There is no long-term trend in the coral $\delta^{18} \mathrm{O}$ record, but there is a long-term trend of increasing coral $\mathrm{Sr} / \mathrm{Ca}$ from 1867 to 1997. This trend in coral $\mathrm{Sr} / \mathrm{Ca}$ suggests a cooling of $\sim 0.7^{\circ} \mathrm{C}$, which is rather unlikely and implies that factors other than SST may be influencing the coral $\mathrm{Sr} / \mathrm{Ca}$ record. The trend in coral $\mathrm{Sr} / \mathrm{Ca}$ is not an analytical artifact, nor a product of time varying riverine input, nor a product of skeletal diagenesis, nor the results of kinetic effects, but may reflect surface-water variability in $\mathrm{Sr} / \mathrm{Ca}$. Despite the presence of a nonclimatic trend in coral $\mathrm{Sr} / \mathrm{Ca}$, the Rabaul coral records contain abundant interannual- to multidecadal-scale variability, much of which is coherent with other proxy records from the WPWP and with instrumental records of ENSO

variability.

Citation: Quinn, T. M., F. W. Taylor, and T. J. Crowley (2006), Coral-based climate variability in the Western Pacific Warm Pool since 1867, J. Geophys. Res., 111, C11006, doi:10.1029/2005JC003243.

\section{Introduction}

[2] The Western Pacific Warm Pool (WPWP) serves as a heat engine for earth's climate and as a major moisture source for earth's hydrological cycle. The WPWP is the region of the equatorial Pacific Ocean where mean annual sea surface temperatures (SST) exceed $28^{\circ} \mathrm{C}$. Thermal and hydrologic variations in the WPWP are intimately involved with variations in the El Niño-Southern Oscillation (ENSO) on interannual timescales, but the role of these variations on sub-centennial timescales remains poorly understood because of the paucity of sub-annually resolved climate and paleoclimate time series from the WPWP.

[3] Rabaul $\left(4^{\circ} \mathrm{S}, 152^{\circ} \mathrm{E}\right)$ is located within the $29^{\circ} \mathrm{C}$ isotherm of the western Pacific mean annual SST field (Figure 1) and is a site dominated by strong atmospheric convection where rainfall exceeds $2 \mathrm{~m} /$ year. The climate of Rabaul is significantly impacted by ENSO dynamics:

\footnotetext{
${ }^{1}$ College of Marine Science, University of South Florida, St. Petersburg, Florida, USA.

${ }^{2}$ Institute for Geophysics, The John A. and Katherine G. Jackson School of Geosciences, University of Texas at Austin, Austin, Texas, USA.

${ }^{3}$ Department of Earth and Ocean Sciences, Nicholas School of the Environment and Earth Sciences, Duke University, Durham, North Carolina, USA.
}

Copyright 2006 by the American Geophysical Union. 0148-0227/06/2005JC003243
ENSO warm phase events (El Niño events) are often characterized by conditions that are cooler and drier than normal, although the response of SST and sea surface salinity (SSS) to ENSO forcing in this region varies considerably. The magnitude of interannual changes in SST and SSS in the ocean waters surrounding Rabaul exceed those of intra-annual changes, which are generally $\sim 1^{\circ} \mathrm{C}$ and $\sim 1$ psu (Figure 2a). Frequency analysis of the SST anomaly (SSTA) record from Rabaul documents major concentrations of variance at $\sim 5.8, \sim 3.6$ and $\sim 2.8$ years; similar periodicities are observed in the SSTA record from the Niño 3.4 region of the eastern tropical Pacific, a widely recognized index of ENSO activity [e.g., Trenberth, 1997].

[4] The few published coral-based climate records from the WPWP are $\delta^{18} \mathrm{O}$ records, which take advantage of the coupling of warm/wet (cool/dry) surface conditions that yield low (high) coral $\delta^{18} \mathrm{O}$ values because of the negative relationship between SST- $\delta^{18} \mathrm{O}$ and the positive relationship between SSS- $\delta^{18} \mathrm{O}$. Century or greater length Porites coral $\delta^{18} \mathrm{O}$ time series from the WPWP have been published from Madang and Laing Island, Papua New Guinea (PNG [Tudhope et al., 1995, 2001]), Nauru [Guilderson and Schrag, 1999], Tarawa [Cole et al., 1993], Maiana [Urban et al., 2000], and Palmyra [Cobb et al., 2001]. All of these coral $\delta^{18} \mathrm{O}$ time series contain a robust record of the timing, frequency and amplitude of ENSO events. These coral $\delta^{18} \mathrm{O}$ records, especially those from Madang and Laing Island, 


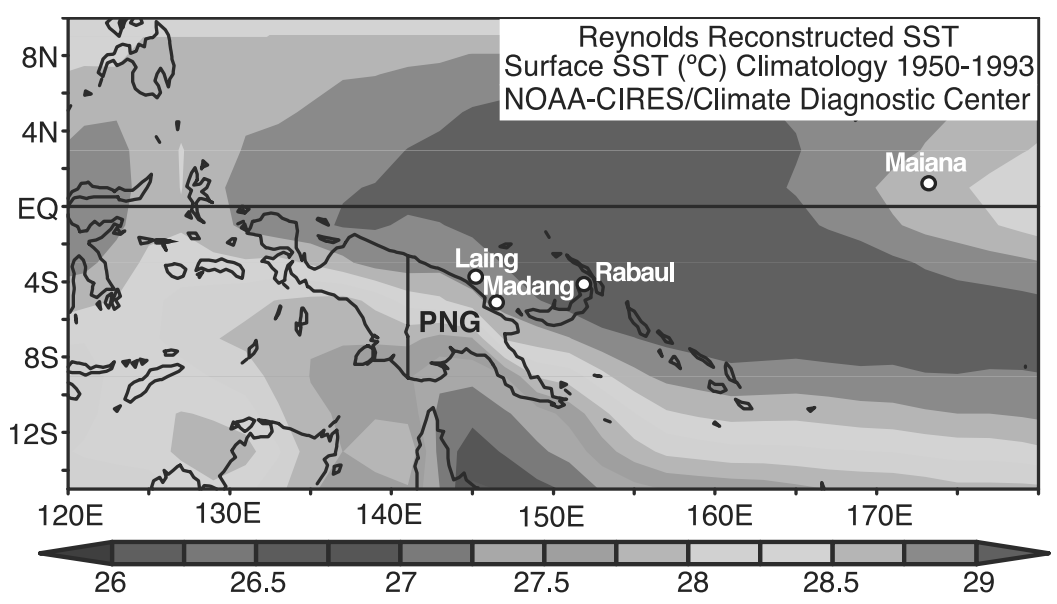

Figure 1. The coral core used in this study was collected offshore of Rabaul, which is located in the warmest sector of the WPWP (mean annual SST $>29^{\circ} \mathrm{C}$ ). Select other sites in the southwestern Pacific where coral climate time series have been generated are also noted.

which are located $<1000 \mathrm{~km}$ to the west of Rabaul, present an opportunity to examine the spatial coherency of the ENSO signal in coral records from WPWP.

[5] The factors controlling variation in coral $\mathrm{Sr} / \mathrm{Ca}$ have been debated over the years with some workers stressing the dominance of the seawater temperature during skeletal aragonite precipitation [e.g., Kinsman and Holland, 1969; Houck et al., 1977; Smith et al., 1979; Beck et al., 1992; Alibert and McCulloch, 1997; Gagan et al., 1998; Marshall and McCulloch, 2002] and others stressing growth parameters (extension, calcification) and biological species effects as having a significant influence on coral skeleton $\mathrm{Sr} / \mathrm{Ca}$ [e.g., Weber, 1973; de Villiers et al., 1994; Cohen et al., 2002; Meibom et al., 2003]. Micron-scale resolution studies of geochemical variations in coral skeletons have provided increased insight into the processes of elemental partitioning, calcification and alteration in corals [e.g., Hart and Cohen, 1996; Cohen et al., 2002; Meibom et al., 2003; Allison and Finch, 2004]. However, as is the case with mmscale studies of coral $\mathrm{Sr} / \mathrm{Ca}$ variations, unresolved issues remain (e.g., influence of calcification rate on skeletal $\mathrm{Sr} / \mathrm{Ca}$; heterogeneity of $\mathrm{Sr} / \mathrm{Ca}$ in skeletal material deposited at night versus the day [Allison and Finch, 2004]). Recent work has also demonstrated that mm-scale determinations of coral $\mathrm{Sr} /$ $\mathrm{Ca}$ are in good agreement with coral $\mathrm{Sr} / \mathrm{Ca}$ records produced by micron-scale sampling when the latter are smoothed using a 60-day filter [Allison et al., 2005]. Application of the coral $\mathrm{Sr} / \mathrm{Ca}$ paleothermometer relies on the assumption that seawater $\mathrm{Sr} / \mathrm{Ca}$ at a single reef site is invariant on submillennial timescales given the long ocean residence times of $\mathrm{Sr}$ and $\mathrm{Ca}\left(\sim 10^{6}\right.$ years [Broecker and Peng, 1982]). Variations in seawater $\mathrm{Sr} / \mathrm{Ca}$ in remote, tropical oligotrophic reef waters have been estimated at $\sim 0.2 \%\left(<0.2^{\circ} \mathrm{C}\right)$, although they may be larger in areas of upwelling [de Villiers et al., 1994]. Seawater $\mathrm{Sr} / \mathrm{Ca}$ varied by $\sim 0.4 \%\left(0.7^{\circ} \mathrm{C}\right)$ as measured over the course of one year in southern Taiwan [Shen et al., 1996]. The observed variability in the Sr/CaSST relationship determined by different authors at different reef localities using the same genus of coral (e.g., Porites $s p$.) has been attributed to differences in seawater $\mathrm{Sr} / \mathrm{Ca}$ at the different reef sites [e.g., Eisenhauer et al., 1999;
DeDeckker, 2004]. Coral Sr/Ca may also be affected by thermal stress, both extreme warm or cool SST excursions [Marshall and McCulloch, 2002]. Studies of coral Sr/Ca variations over several years to several decades in multiple coral heads from the same reef document the highly reproducible nature of coral $\mathrm{Sr} / \mathrm{Ca}$ records when care is taken to sample the corals along their major growth axes [e.g., Alibert and McCulloch, 1997; Stephans et al., 2004]. However, only a few, long ( $>100$ years) coral $\mathrm{Sr} / \mathrm{Ca}$ records have been published to date: the 271 year, bimonthly resolved record from Rarotonga [Linsley et al., 2000]; the 217 year, bimonthly resolved record from Fiji [Linsley et al., 2004]; the 420 year, pentannually resolved record from the Great Barrier Reef [Hendy et al., 2002]; and the $>300$ year, monthly resolved record from New Caledonia [DeLong et al., 2005]. Additional century-scale coral $\mathrm{Sr} / \mathrm{Ca}$ records are needed to better understand the factors responsible for coral $\mathrm{Sr} / \mathrm{Ca}$ variations and to assess the spatial and temporal coherency of these records.

[6] Herein we report coral $\delta^{18} \mathrm{O}$ and $\mathrm{Sr} / \mathrm{Ca}$ time series (1997-1867) from the warmest sector of the WPWP, which adds to the growing number of coral-climate records from this climatically significant region. The coral $\mathrm{Sr} / \mathrm{Ca}$ time series is the first of its kind from the WPWP and provides an opportunity to examine the factors that influence coral $\mathrm{Sr} / \mathrm{Ca}$ over the past $\sim 130$ years in the core of the WPWP.

\section{Materials and Methods}

[7] A $\sim 1.8 \mathrm{~m}$ Porites lobata coral head was recovered in $\sim 8 \mathrm{~m}$ of water from offshore of Rabaul, East New Britain, Papua New Guinea in September, 1998. A 5-mm thick slab of the coral core was sampled for geochemical analyses every $0.625 \mathrm{~mm}$ along the major axis of coral growth (Figure 3). Petrographic thin sections and SEM images were examined for evidence of secondary minerals; none was observed in the $0-174 \mathrm{~cm}$ section of the coral core used in this study. The basal section of the core was not used in this study because it is characterized by extensive evidence of alteration [Quinn and Taylor, 2006].

[8] Stable isotopic and elemental ratio determinations were made on splits of the same powder using instrumen- 


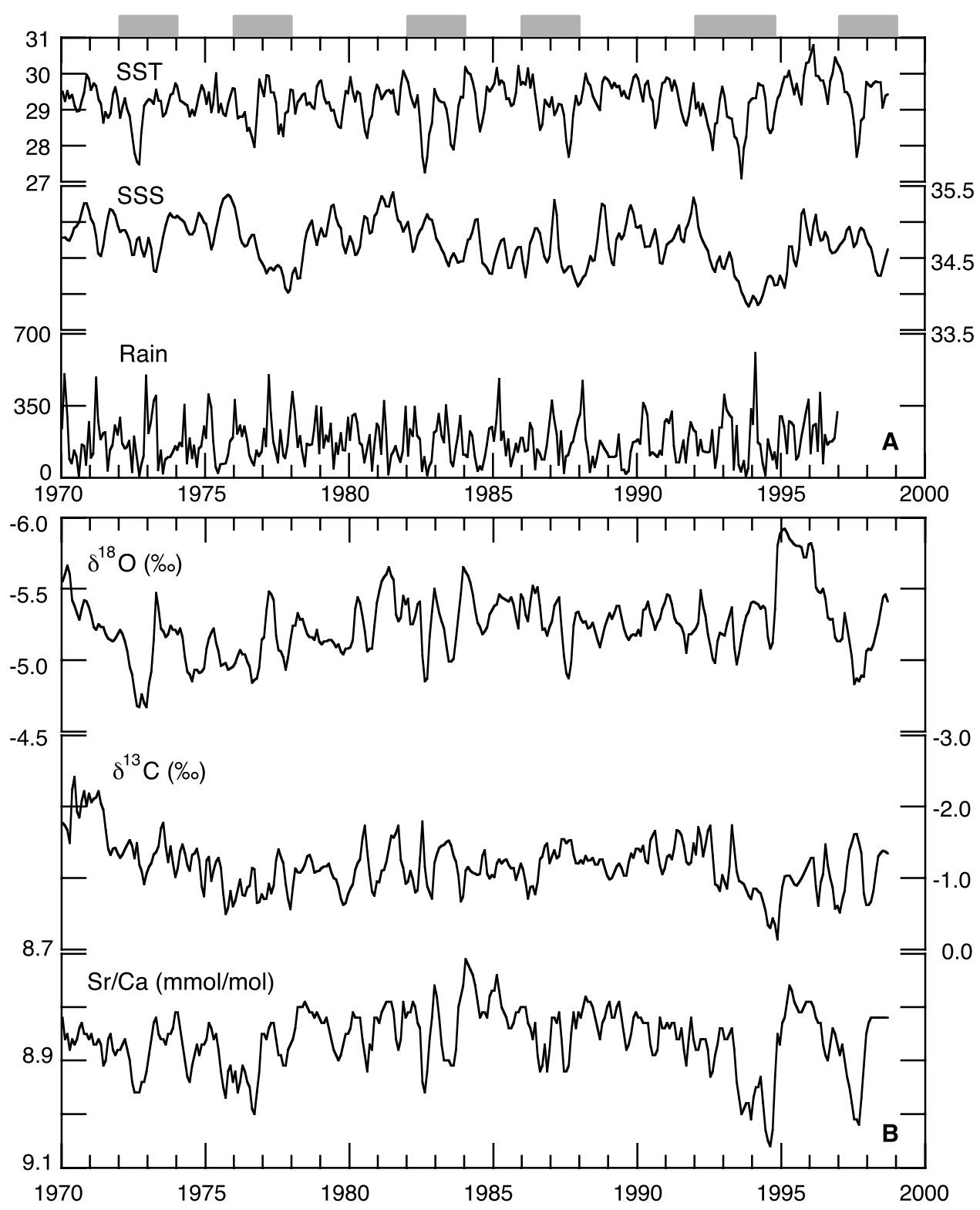

Figure 2. (a) Variations in sea surface temperature (SST [Rayner et al., 2003]), sea surface salinity (SSS [Delcroix et al., 2005]), and rainfall (National Weather Center, Climate Prediction Center website) in the Rabaul region. Timing of ENSO warm phase (El Nino) events is noted with the stippled rectangles at top of plot. See text for sources of data. (b) Variations in skeletal geochemistry of a Rabaul coral: $\delta^{18} \mathrm{O}, \delta^{13} \mathrm{C}$ and $\mathrm{Sr} / \mathrm{Ca}$.

tation at the University of South Florida (USF; ThermoFinnigan DeltaPlus with Kiel III carbonate device and Perkin Elmer 4300 DV Inductively Coupled Plasma Optical Emissions Spectrometer). Stable isotopic precision, based on daily measurements of laboratry standards $(\mathrm{N}>500)$ over the past 12 months, is \pm 0.06 per mil $(1 \sigma)$ for oxygen, \pm 0.03 per mil $(1 \sigma)$ for carbon. All values are reported in standard delta notation relative to the VPDB isotopic standard using the conventional notation. Analytical precision for $\mathrm{Sr} / \mathrm{Ca}$ determinations, based on repeated measurements of an internal gravimetric standard ( $\mathrm{n}>25,000)$, is $\pm 0.14 \%(2 \sigma ; \pm 0.013 \mathrm{mmol} / \mathrm{mol})$ and is $\pm 0.25 \%(2 \sigma$; $\pm 0.022 \mathrm{mmol} / \mathrm{mol}$ ) based on repeated measurements of a homogenized coral powder $(n>600)$. The pooled standard deviation of $>100 \mathrm{Sr} / \mathrm{Ca}$ analyses on replicate samples is $0.030 \mathrm{mmol} / \mathrm{mol}$. The accuracy of our standard's $\mathrm{Sr} / \mathrm{Ca}$ value has been externally verified by TIMS analysis at the University of Minnesota Isotope Laboratory.

[9] Age models were constructed using the AnalySeries program [Paillard et al., 1996]. We used tie points to connect the lowest (highest) $\delta^{18} \mathrm{O}$ values to the warmest (coolest) temperatures in the instrumental SST record to establish each year. The use of coral $\mathrm{Sr} / \mathrm{Ca}$ values instead of coral $\delta^{18} \mathrm{O}$ values to construct the age model results produces a similar chronology. The geochemical data were then interpolated to give monthly $\delta^{18} \mathrm{O}$ values (and corresponding paired $\delta^{13} \mathrm{C}$ and $\mathrm{Sr} / \mathrm{Ca}$ values) to compare to the instrumental SST and SSS data. The period 1970- 


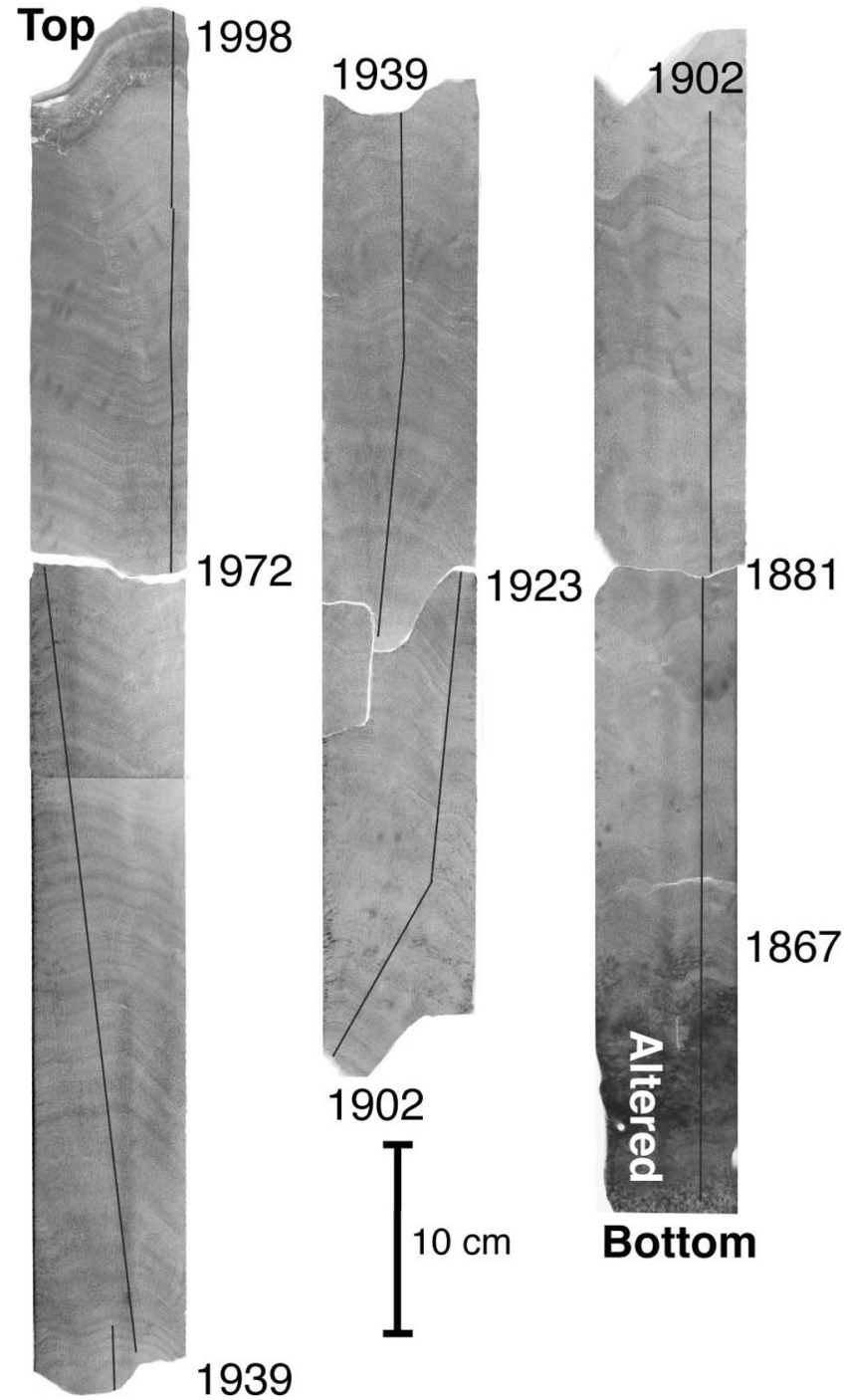

Figure 3. X-radiograph positive image of Rabaul coral 98RK3. Solid black lines denote sampling path used to extract samples for geochemical analyses. The pre-1867 interval is altered; no samples from this altered interval were used in this study.

1993 was used for comparisons between the instrumental and coral records because this is the common period of overlap amongst all of the records and because the post1993 interval in each of the time series is disturbed by strong episode of extended volcanism of the Tavurvur volcano in Rabaul. The monthly geochemical time series were also cast in terms of anomalies by averaging the geochemical value for each month over the interval 1979-1950 and subtracting these monthly averages from the corresponding monthly value over the entire geochemical time series following the convention of Trenberth [1997]. The geochemically based age models were confirmed via comparison with ages determined by counting of skeletal density-band couplets in the X-ray images of the coral slab. Average skeletal extension rate is $\sim 13 \mathrm{~mm} /$ year; there is little variability in this rate (Figure 4).
[10] The AnalySeries program [Paillard et al., 1996] was also used to filter the various time series. A Gaussian bandpass filter was constructed to highlight ENSO variability in the records. The central frequency of this ENSO filter is $0.2750 \pm 0.1275$, which isolates the 3 to 7 year periods in the records. Wavelet analysis [Torrence and Compo, 1998] was also applied to the various time series to determine the dominant modes of climate variability in the data and how these modes have varied with time. We used the web-based, interactive wavelet program at http://paos.colorado.edu/ research/wavelets/ in this study.

[11] Local, in situ records of SST and SSS are not available at Rabaul. The SST time series used in this study were extracted from the $4^{\circ} \mathrm{S}, 152^{\circ} \mathrm{E}$ grid point of the HadlSST 1.1 SST database [Rayner et al., 2003]. SST time series from other gridded SST products (NCEP and Reynolds OI) extracted from the Rabaul coordinates agree well with the time series from HadISST and the HadlSST 1.1 SST data are used exclusively in this study. For salinity, we examined three datasets: New Caledonia to Japan ship-track (PX05 [Delcroix et al., 2005]), NCEP SSS [Behringer et al., 1998] and WOA94 [Levitus et al., 1994]. Ship-track PX05 extends from about $30^{\circ} \mathrm{N}-142^{\circ} \mathrm{E}$ to $30^{\circ} \mathrm{S}-170^{\circ} \mathrm{E}$, hence passing by Rabaul $\left(4^{\circ} \mathrm{S}\right)$ near $158^{\circ} \mathrm{E}$. The width of the track is about $15^{\circ}$ of longitude. We note that none of these records are in situ, instrumental records of SSS variability at the Rabaul reef site and that large differences amongst the records complicate, and perhaps compromise, comparisons with coral proxy records of salinity variations. Rainfall data for Rabaul were downloaded from the National Weather Center, Climate Prediction Center website (http:// www.cpc.noaa.gov/products/pacdir/NCLIM.shtml). The available instrumental data from the Rabaul region indicate

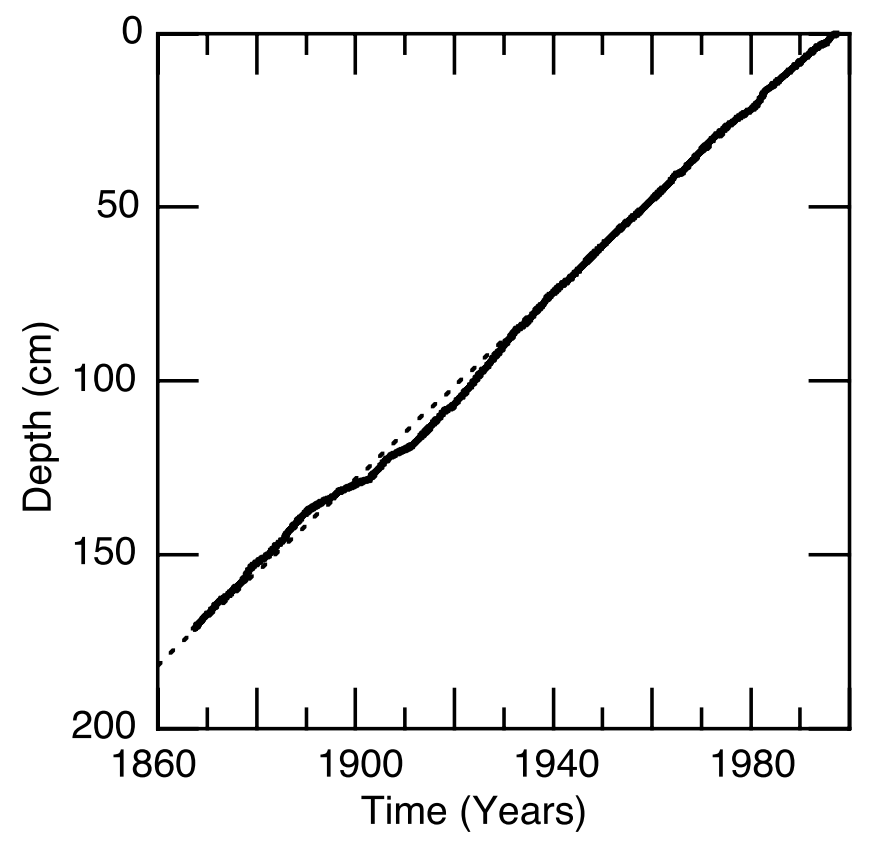

Figure 4. Age versus depth plot for coral core 98RK3 (solid line) and a linear best fit between the two variables (dashed line; $r^{2}=0.99$ ). Skeletal extension rate averages $1.33 \mathrm{~cm} /$ year over the length of the record. 


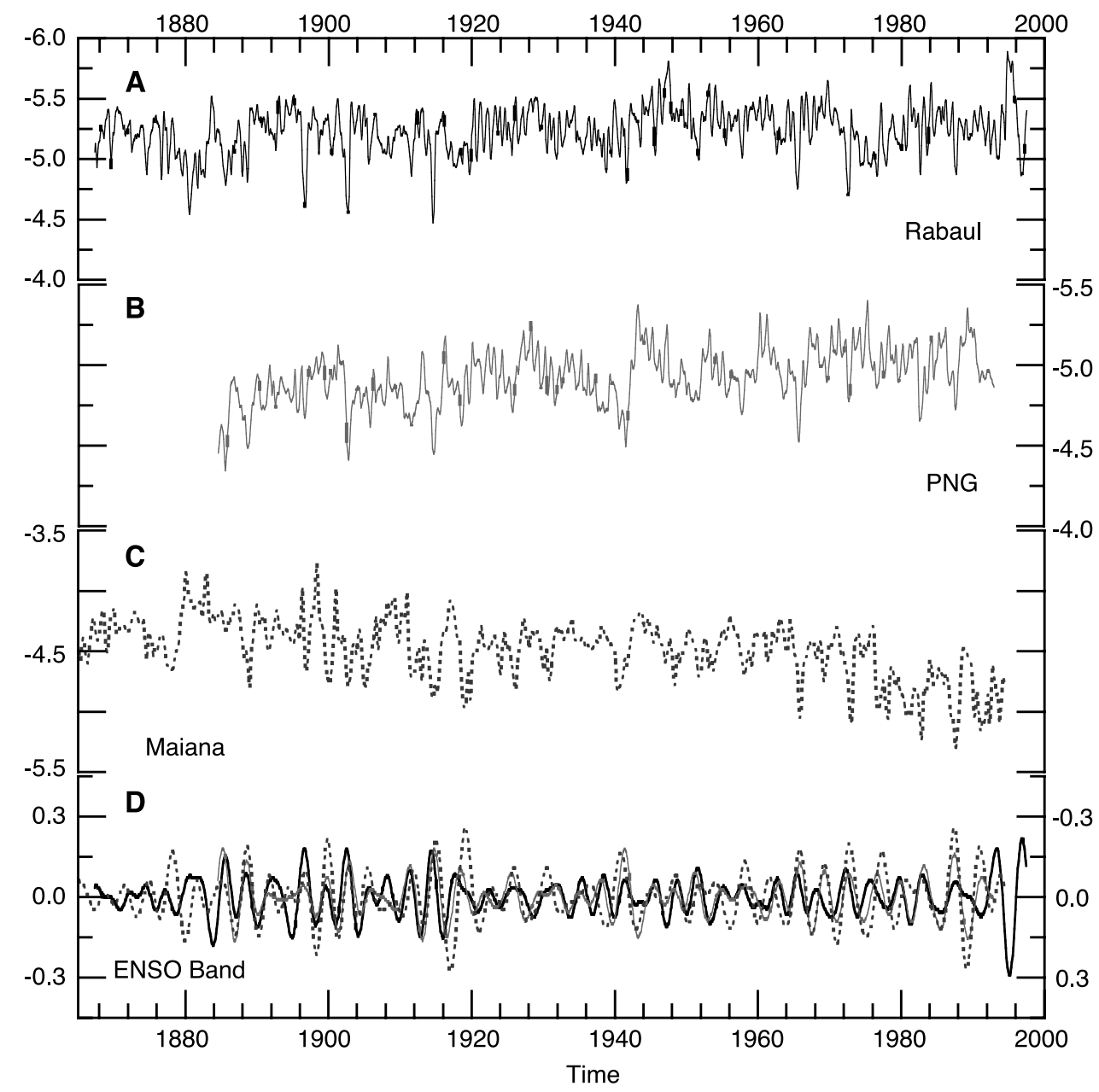

Figure 5. Oxygen isotopic variations (\%o) in corals from the Western Pacific Warm Pool: (a) Rabaul (this study; thick line); (b) Papua New Guinea (PNG [Tudhope et al., 2001]; thin line); (c) Maiana ([Urban et al., 2000]; dashed line). Each of these time series was normalized and then filtered (d) with a Gaussian filter (frequency, 0.2750; bandwidth, 0.1275) to highlight interannual variability, which is common amongst the time series.

a complex relationship between seasonal and interannual variations in SST, SSS and rainfall (Figure 2a).

\section{Results}

[12] The $\delta^{18} \mathrm{O}, \delta^{13} \mathrm{C}$ and $\mathrm{Sr} / \mathrm{Ca}$ records from core 98RK-3 (Figures 2b, 5, and 6) display seasonal cycles, as well as significant interannual variability. There is no discernible long-term trend in the $\delta^{18} \mathrm{O}$ time series, but there is a trend towards increasing values through the 20th century in the $\mathrm{Sr} / \mathrm{Ca}$ time series. The $\delta^{13} \mathrm{C}$ record provides additional constraints on the chronology of the core. The statistical relation between coral and environmental variables between 1970-1993 is reported in Table 1.

\section{Discussion}

\subsection{Oxygen Isotopic Variations With Time}

[13] Coral $\delta^{18} \mathrm{O}$ variations at Rabaul are likely driven by the combined variations in SST and seawater $\delta^{18} \mathrm{O}$ (and hence SSS) given the general climatology of the WPWP. However, the timing of changes in SST and SSS at Rabaul need not coincide (Figure 2a), hence the traditional warm/ wet-cool/dry perspective which would impart an additive effect on the coral $\delta^{18} \mathrm{O}$ signal may not be applicable at Rabaul. Coral $\delta^{18} \mathrm{O}$ variations are modestly correlated with SST variations over their common period of overlap (19701993), both in terms of the monthly and monthly anomaly time series (Table 1 ). The monthly coral $\delta^{18} \mathrm{O}$ anomaly time series at Rabaul yields no significant correlation with the instrumental SSS record, despite the fact that similar coral records from Fiji [ $\mathrm{Le} \mathrm{Bec}$ et al., 2000] and Vanuatu [Kilbourne et al., 2004] have been demonstrated to reflect SSS variations. It is possible that the monthly coral $\delta^{18} \mathrm{O}$ anomaly record does reflect local SSS variability at Rabaul and the observed low correlation between these two variables results from differences between the ship-track SSS record and the actual SSS variability at Rabaul. These modest to low correlations between coral $\delta^{18} \mathrm{O}$ and SST variations may reflect the variable phasing between changes in SST and SSS which produces an inconsistent damping effect on the amplitude of the coral $\delta^{18} \mathrm{O}$ signal because of the opposite relationship between coral $\delta^{18} \mathrm{O}-\mathrm{SST}$ (negative) 


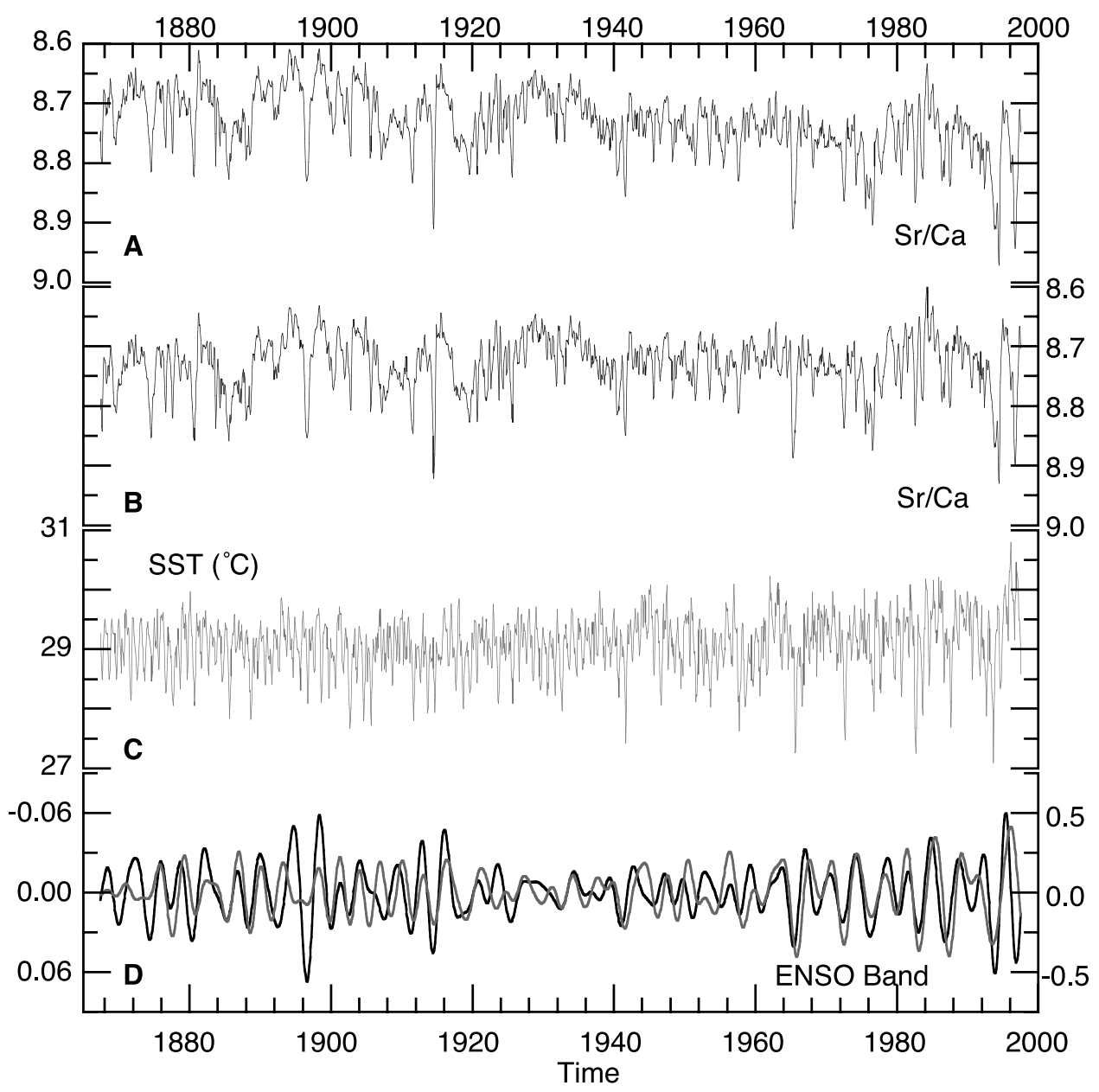

Figure 6. Time series of coral $\mathrm{Sr} / \mathrm{Ca}, \mathrm{SST}$, and filtered versions of these records. (a) Coral $\mathrm{Sr} / \mathrm{Ca}$ variations ( $\mathrm{mmol} / \mathrm{mol})$. (b) Coral $\mathrm{Sr} / \mathrm{Ca}$ variations $(\mathrm{mmol} / \mathrm{mol})$ with the long-term trend of increasing $\mathrm{Sr} / \mathrm{Ca}$ values removed. (c) SST $\left({ }^{\circ} \mathrm{C}\right.$ ) at Rabaul as extracted from the appropriate $1^{\circ} \times 1^{\circ}$ grid box of the HadISST1.1 database [Rayner et al., 2003]. The detrended and normalized coral Sr/Ca and the SST time series were each filtered (d) with a Gaussian filter (frequency, 0.2750; bandwidth, 0.1275) to highlight interannual variability, which is common between the time series.

and coral $\delta^{18} \mathrm{O}$-SSS (positive). In addition, the amplitude of the annual cycle in SST is highly variable and sometimes difficult to discern at Rabaul (Figure 2a), which adds to the challenge of a $\delta^{18} \mathrm{O}$-based reconstruction of SST because this variability tends to decrease the signal-to-noise ratio in the coral $\delta^{18} \mathrm{O}$ signal.

[14] The coral $\delta^{18} \mathrm{O}$ record at Rabaul does capture the signal associated with interannual climate variability in the surface ocean of the tropical Pacific as demonstrated by its coherency with other climate records in the Pacific basin. Large, positive excursions in the coral $\delta^{18} \mathrm{O}$ time series all coincide with ENSO warm phase events as defined using the criteria defined by Trenberth [1997] with the exception of the isotopic event centered at 1880 . Comparisons between the coral $\delta^{18} \mathrm{O}$ record at Rabaul with records from PNG [Tudhope et al., 1995, 2001] and Maiana [Urban et al., 2000] demonstrate an in-phase relation between the records at Rabaul and PNG and an out-of-phase relation between these records and the Maiana record (Figure 5), which is especially evident in the ENSO frequency band (Figure $5 \mathrm{~d}$ and Table 2). A changing pattern of interannual variability ranging from large amplitude oscillations between 1880 and 1920, to low amplitude oscillations between 1920 and 1960, and a return to large amplitude oscillations post-1960, which has been previously identified in the instrumental SST anomaly record from the NINO3.4 grid box [Torrence and Webster, 1999] and in coral $\delta^{18} \mathrm{O}$ time series (e.g., PNG [Tudhope et al.,

Table 1. Summary of Correlations Between Coral Geochemistry and Surface-Ocean Variables ${ }^{\mathrm{a}}$

\begin{tabular}{lccccccc}
\hline $1993-1970$ & $\mathrm{SST}$ & $\mathrm{SSS}$ & $\delta^{18} \mathrm{O}$ & $\delta^{13} \mathrm{C}$ & $\mathrm{Sr} / \mathrm{Ca}$ & $\Delta \delta^{18} \mathrm{O}$ & Rainfall \\
\hline $\mathrm{SST}$ & 1 & 0.15 & -0.55 & 0.02 & -0.66 & -0.15 & 0.28 \\
$\mathrm{SSS}$ & 0.14 & 1 & -0.01 & -0.18 & -0.06 & 0.06 & -0.12 \\
$\delta^{18} \mathrm{O}$ & -0.53 & 0.01 & 1 & 0.15 & 0.67 & 0.74 & -0.19 \\
$\delta^{13} \mathrm{C}$ & 0.06 & -0.19 & 0.16 & 1 & 0.04 & 0.17 & 0.06 \\
$\mathrm{Sr} / \mathrm{Ca}$ & -0.66 & -0.06 & 0.66 & 0.02 & 1 & 0.19 & -0.19 \\
$\Delta \delta^{18} \mathrm{O}$ & -0.12 & 0.06 & 0.75 & 0.19 & -0.00 & 1 & -0.22 \\
Rainfall & 0.30 & -0.12 & -0.19 & 0.06 & -0.20 & -0.23 & 1 \\
\hline
\end{tabular}

${ }^{a}$ Values in italics (upper right) reflect anomalies, calculated as the difference between each monthly observation from the climatological average of the pooled monthly observations between 1993 and 1970 . Values in regular text (lower left) reflect relationship between individual monthly observations. 
Table 2. Summary of Correlations Between Various Coral Geochemistry Records, the SOI Index and SST at Rabaul ${ }^{\mathrm{a}}$

\begin{tabular}{lcccccc}
\hline & SOI & $\begin{array}{c}\text { PNG } \\
\delta^{18} \mathrm{O}\end{array}$ & $\begin{array}{c}\text { Maiana } \\
\delta^{18} \mathrm{O}\end{array}$ & $\begin{array}{c}\text { Rabaul } \\
\delta^{18} \mathrm{O}\end{array}$ & $\begin{array}{c}\mathrm{Rabaul} \\
\mathrm{Sr} / \mathrm{Ca}\end{array}$ & $\begin{array}{c}\text { Rabaul } \\
\text { SST }\end{array}$ \\
\hline SOI & 1 & & & & & \\
PNG $\delta^{18} \mathrm{O}$ & -0.53 & 1 & & & & \\
Maiana $\delta^{18} \mathrm{O}$ & 0.81 & -0.64 & 1 & & & \\
Rabaul $\delta^{18} \mathrm{O}$ & -0.30 & 0.57 & -0.28 & 1 & & \\
Rabaul Sr/Ca & -0.44 & 0.56 & -0.44 & 0.73 & 1 & \\
Rabaul SST & 0.71 & -0.67 & 0.67 & -0.51 & -0.49 & 1 \\
\hline
\end{tabular}

${ }^{\mathrm{a}}$ Each of these records has been filtered to highlight ENSO variations using a Gaussian filter with a frequency of 0.2750 and a bandwidth of 0.1275 .
2001] and Maiana [Urban et al., 2000]), is also observed in the Rabaul coral $\delta^{18} \mathrm{O}$ record (Figure $5 \mathrm{~d}$ ).

[15] Wavelet analysis of the coral $\delta^{18} \mathrm{O}$ record at Rabaul documents a time varying response of the variability in the record (Figure 7a). Diminution of spectral power in the ENSO frequency band is observed in the middle of the 20th century, which is similar to that observed in the filtered results (Figure 5d). Decadal to multidecadal variability (Figures $7 \mathrm{a}$ and 8 ) in coral $\delta^{18} \mathrm{O}$ seems especially strong in the post-1950s interval.

\subsection{Sr/Ca Variations With Time}

[16] Coral $\mathrm{Sr} / \mathrm{Ca}$ variations are well correlated with coral $\delta^{18} \mathrm{O}$ variations from monthly, monthly anomaly, and
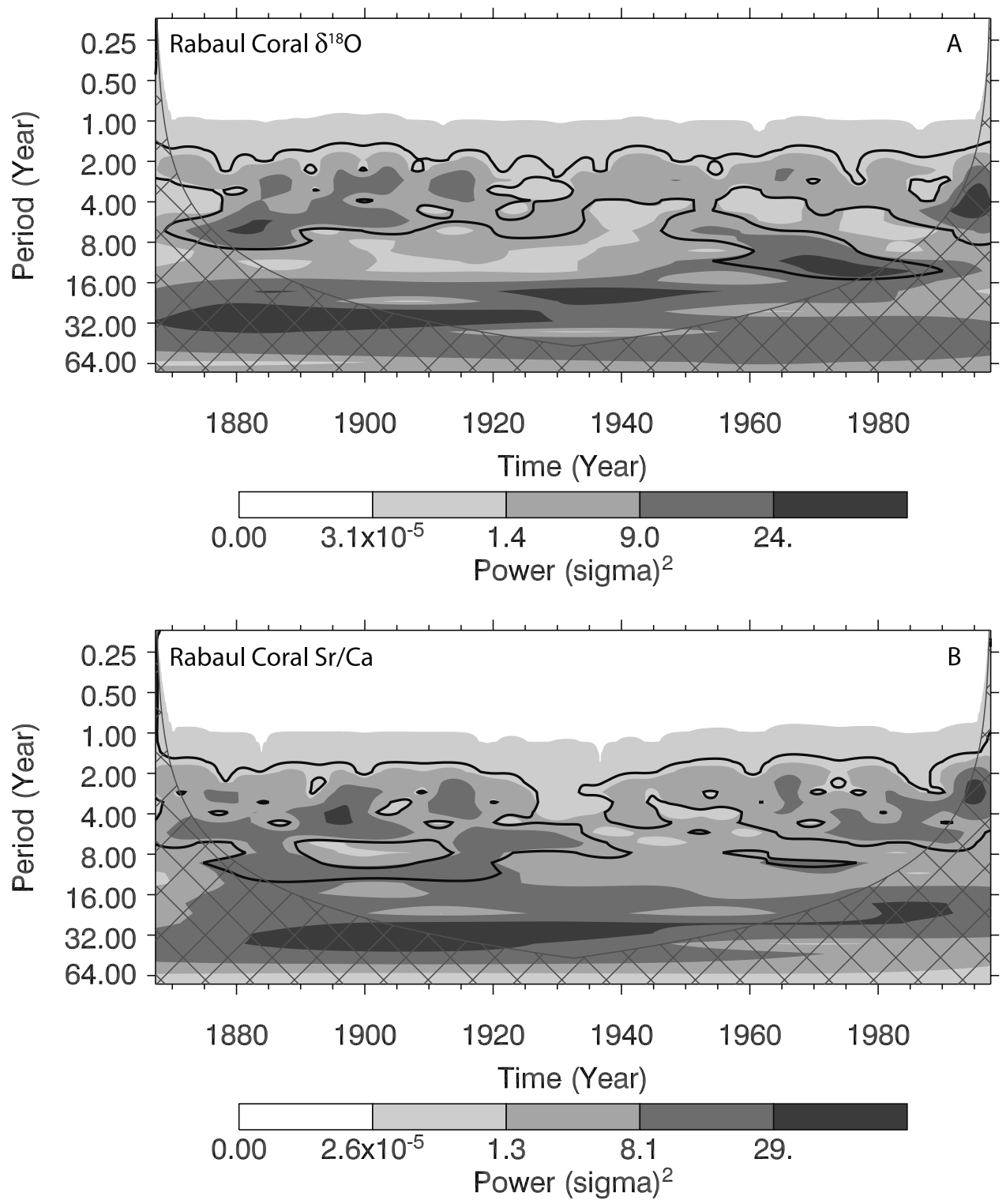

Figure 7. Wavelet power spectrum: Rabaul coral $\delta^{18} \mathrm{O}$ (top) and $\mathrm{Sr} / \mathrm{Ca}$ (bottom) records. Each of these records have been normalized and filtered to remove subannual variations. The contour levels are chosen so that $75 \%, 50 \%, 25 \%$, and $5 \%$ of the wavelet power is above each level, respectively. The cross hatch region is the cone of influence, where zero padding has reduced the variance. Black contour is the $10 \%$ significance level, using a red-noise (autoregressive lag1) background spectrum. A Morlet wavelet of 10 was used in both cases. Program accessed through http://paos.colorado.edu/research/wavelets/ based on the work of Torrence and Compo [1998]. 


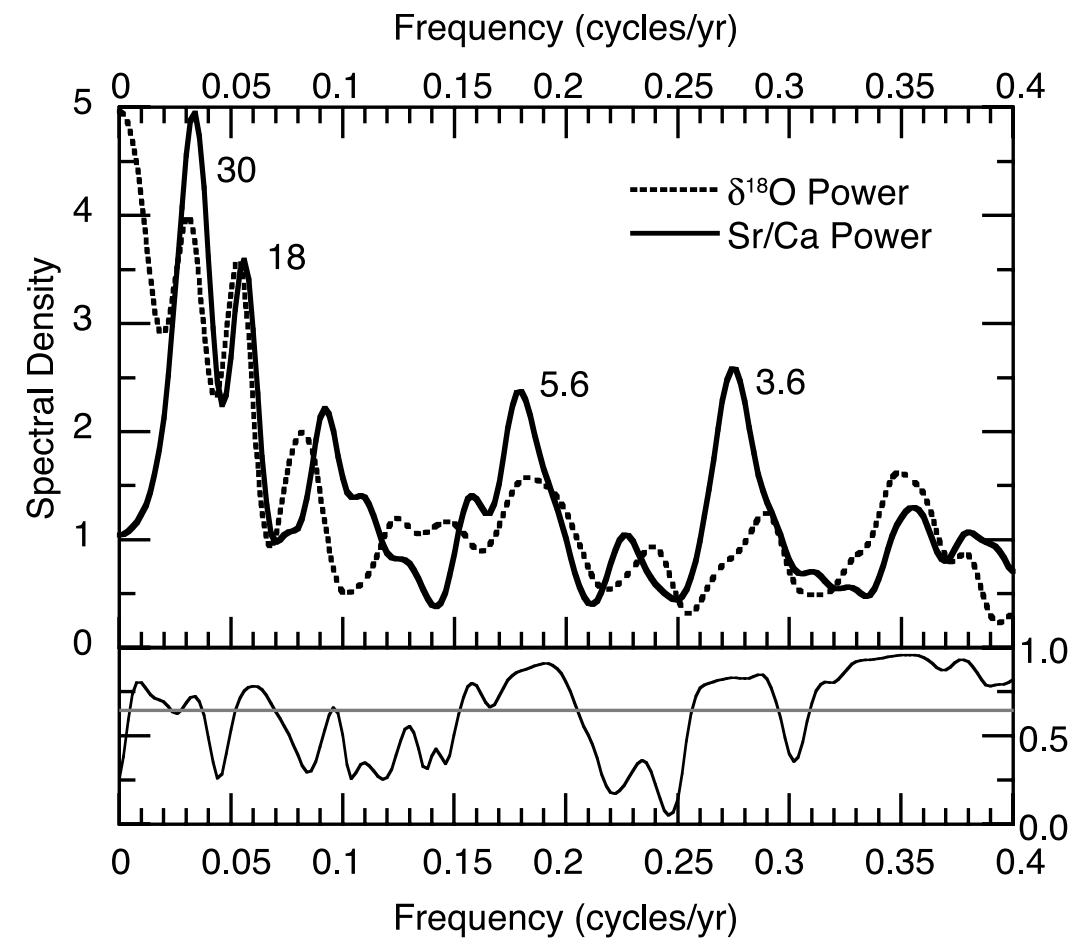

Figure 8. Blackman-Tukey cross-spectral analysis of coral $\delta^{18} \mathrm{O}$ and coral $\mathrm{Sr} / \mathrm{Ca}$ records using a Bartlett window (top). The coral records were normalized and resampled to bi-annual resolution prior to analysis. The bandwidth is 0.02299 . Nonzero coherence (bottom) is higher than 0.665 . The error estimation on the power spectrum is $0.415<\Delta$ Power/Power $<4.870$.

ENSO-filtered perspectives (Tables 1 and 2). Coral $\mathrm{Sr} / \mathrm{Ca}$ variations are also correlated with SST variations (Table 1), although these correlations are weaker than reported in most other studies documenting the Porites Sr/Ca-SST relationship [e.g., Alibert and McCulloch, 1997; Marshall and McCulloch, 2002; Quinn and Sampson, 2002; Stephans et al., 2004]. Despite the modest correlation between monthly variations in coral Sr/Ca and SST between 1970-1993, the linear least squares equation relating these two time series at Rabaul (SST $\left({ }^{\circ} \mathrm{C}\right)=(10.640-\mathrm{Sr} / \mathrm{Ca}) /-0.061$ has a slope value that is similar to equations generated at other localities for Porites corals [e.g., Gagan et al., 2000; Corrège, 2006].

[17] There is a strong correspondence between positive excursions in coral $\mathrm{Sr} / \mathrm{Ca}$ and cool excursions in the instrumental SST record (Figure 6) and the timing of such excursions is entirely consistent with the timing of known ENSO warm phase events. However, there is a long-term trend of increasing coral $\mathrm{Sr} / \mathrm{Ca}$ values from 1867 to 1997 that is not observed in the SST record (see Figures 6a and $6 \mathrm{c}$ ). This coral $\mathrm{Sr} / \mathrm{Ca}$ trend, if interpreted solely as a change in SST, would indicate cooling of $\sim 0.7^{\circ} \mathrm{C}$ over this time. This inferred cooling contrasts with most other observations in the region over this time interval and is not observed in the coral $\delta^{18} \mathrm{O}$ record.

[18] The cause of the discrepancies between the SST and the coral $\mathrm{Sr} / \mathrm{Ca}$ records at Rabaul is unclear and we explore causal scenarios. The long-term trend in coral $\mathrm{Sr} / \mathrm{Ca}$ is not an analytical artifact because replicate $\mathrm{Sr} / \mathrm{Ca}$ analyses performed after the original $\mathrm{Sr} / \mathrm{Ca}$ analyses confirm the robustness of the trend. The trend is also not produced by changes in riverine input as no rivers drain into the coastal waters where the coral used in this study lived. We also conclude that diagenesis is not responsible for the $\mathrm{Sr} / \mathrm{Ca}$ trend because analysis of petrographic thin-sections and SEM images indicate that no secondary carbonate minerals are present in the upper $176 \mathrm{~cm}$ of the Rabaul coral core [Quinn and Taylor, 2006]. We also note that there is no significant relationship between coral $\mathrm{Sr} / \mathrm{Ca}$ variations and extension rate in the Rabaul coral (Figure 4) and hence conclude that kinetic effects are also not responsible for the observed trend. The next suite of possibilities assumes that the coral $\mathrm{Sr} / \mathrm{Ca}$ is accurately recording primary surface-ocean variability in $\mathrm{SST}$ and/or seawater $\mathrm{Sr} / \mathrm{Ca}$. If seawater $\mathrm{Sr} / \mathrm{Ca}$ at Rabaul has been invariant during coral growth then the difference in variability between the coral $\mathrm{Sr} / \mathrm{Ca}-\mathrm{SST}$ and gridded SST variability may be a manifestation of the difference between SST at a local reef site, as inferred from coral $\mathrm{Sr} / \mathrm{Ca}$, compared with a $1^{\circ}$ by $1^{\circ}$ gridded SST product. We cannot make a proper assessment of this scenario because an in situ SST data set from Rabaul does not exist. Alternatively, the difference between the gridded SST and the coral $\mathrm{Sr} / \mathrm{Ca}-\mathrm{SST}$ may be evidence that variations in seawater $\mathrm{Sr} / \mathrm{Ca}$ at Rabaul are contributing to the coral $\mathrm{Sr} / \mathrm{Ca}$ signal. These potential changes might result from proximal and/or distal forcing. Seasonal changes in seawater $\mathrm{Sr} / \mathrm{Ca}$ have been documented offshore of Taiwan [Shen et al., 1996] and perhaps such changes also occur at Rabaul. Variations in seawater $\mathrm{Sr} / \mathrm{Ca}$ in response to upwelling of nutrient-rich waters at Galapagos have been reported [de Villiers et al., 1994], but there are no reports of upwelling at the Rabaul reef sites. Upwelling of nutrient-rich waters from depth is particularly unlikely at Rabaul because the WPWP 


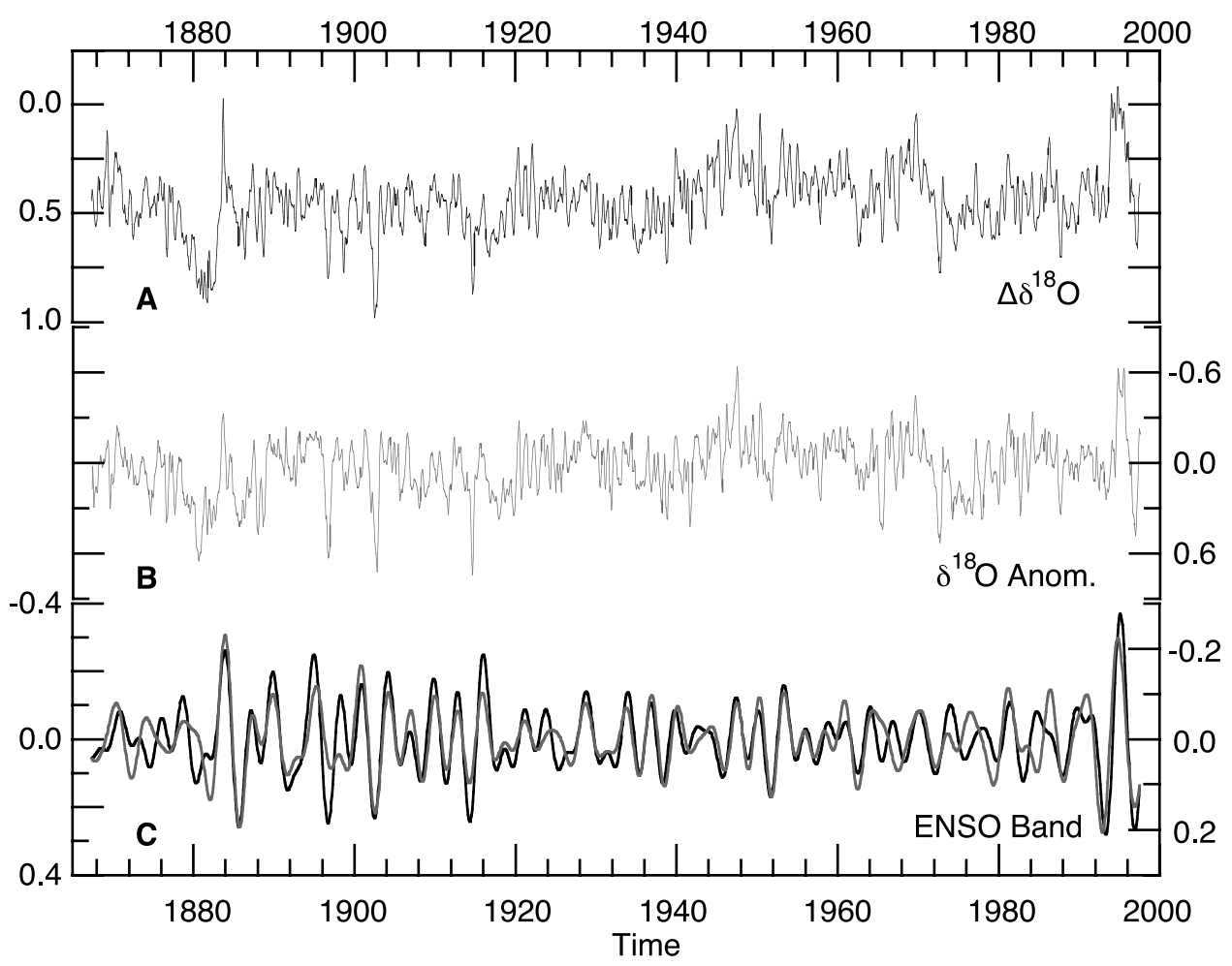

Figure 9. Time series of (a) $\Delta \delta^{18} \mathrm{O}(\%)$, (b) coral $\delta^{18} \mathrm{O}$ anomaly (\%), and (c) the normalized and filtered versions of these records. The $\Delta \delta^{18} \mathrm{O}$ time series is produced by removing the temperature component of the coral $\delta^{18} \mathrm{O}$ signal using the coral $\mathrm{Sr} / \mathrm{Ca}$ record, which leaves a resultant signal that is an estimate of seawater $\delta^{18} \mathrm{O}$ [see Gagan et al., 1998]. The coral $\delta^{18} \mathrm{O}$ anomaly time series is produced by removing the monthly climatological average value of coral $\delta^{18} \mathrm{O}$ for the period $1979-1950$ from the corresponding monthly value over the entire coral $\delta^{18} \mathrm{O}$ record. The $\Delta \delta^{18} \mathrm{O}$ and the coral $\delta^{18} \mathrm{O}$ anomaly records were each filtered (Figure 9c) with a Gaussian filter (frequency, 0.2750; bandwidth, 0.1275) to highlight interannual variability, which is common between the time series.

is characterized by a deep thermocline. Another possible cause of the observed coral $\mathrm{Sr} / \mathrm{Ca}$ trend at Rabaul might be changes in the sources of water that baths the reef sites at Rabaul. For example, Guilderson et al. [2004] used a coral $\Delta^{14} \mathrm{C}$ record from Guadalcanal, Solomon Islands $\left(9^{\circ} \mathrm{S}\right.$, $160^{\circ} \mathrm{E}$ ) and a simple mixing model between southern subtropical and eastern tropical water to infer that the proportion of waters derived from the eastern Pacific entering the Solomon Sea over the past 20 years has decreased. Unfortunately no seawater $\mathrm{Sr} / \mathrm{Ca}$ or coral radiocarbon measurements have been made at Rabaul, thus the possible causes of the long-term trend in the coral $\mathrm{Sr} / \mathrm{Ca}$ at Rabaul cannot be constrained. Additional coral $\mathrm{Sr} / \mathrm{Ca}$ records from the WPWP are needed to assess whether the long-term trend in the Rabaul coral $\mathrm{Sr} / \mathrm{Ca}$ record is observed in other regions or is site specific. If this trend is replicated then this site becomes a good choice for seawater-sampling program. Whatever explanation is developed to account for the long-term, nonclimatic trend in the coral $\mathrm{Sr} / \mathrm{Ca}$ record must also account for the retention of a strong interannual to multidecadal climate signal as demonstrated by the results of time series analysis.

[19] Prior to time series analysis of the coral $\mathrm{Sr} / \mathrm{Ca}$ time series the trend was removed using a linear regression model (Figure 6b). This detrended coral $\mathrm{Sr} / \mathrm{Ca}$ record was used in all statistical and frequency domain analyses.
Filtering the coral $\mathrm{Sr} / \mathrm{Ca}$ and $\mathrm{SST}$ records to highlight variability in the ENSO frequency band documents that coral $\mathrm{Sr} / \mathrm{Ca}$ also captures periods of strengthened interannual variability between $1867-1920$ and 1960-1997 (Figures $6 \mathrm{~d}$ and $7 \mathrm{~b}$ ). This pattern of strong-weak-strong interannual variability has been recognized before in coral $\delta^{18} \mathrm{O}$ [e.g., Tudhope et al., 1995, 2001; Urban et al., 2000], but has not previously been identified in a coral $\mathrm{Sr} / \mathrm{Ca}$ record. Coral $\mathrm{Sr} / \mathrm{Ca}$ variations at Rabaul are coherent with coral $\delta^{18} \mathrm{O}$ variations (Figure 8), suggesting that both proxies are responding to similar forcing, especially at the interannual to multidecadal time scales. Wavelet analysis of the coral $\mathrm{Sr} / \mathrm{Ca}$ record at Rabaul also documents the diminution of spectral power in the interannual band in the middle of the 20th century, as is also observed in the coral $\delta^{18} \mathrm{O}$ record. Decadal to multidecadal variability (Figures $7 \mathrm{~b}$ and 8 ) in coral $\mathrm{Sr} / \mathrm{Ca}$ is especially strong in the pre-1950s interval, which contrasts with similar variability in the coral $\delta^{18} \mathrm{O}$ record.

\section{3. "Seawater" $\delta^{18} \mathrm{O}$ Variations With Time}

[20] The paired determinations of coral $\delta^{18} \mathrm{O}$ and $\mathrm{Sr} / \mathrm{Ca}$ at Rabaul provide the opportunity to examine potential changes in hydrologic balance in the WPWP by estimating seawater $\delta^{18} \mathrm{O}$ by using $\mathrm{Sr} / \mathrm{Ca}$-SST to subtract the temperature component from the coral $\delta^{18} \mathrm{O}$ signal [e.g., 
McCulloch et al., 1994; Gagan et al., 1998; Ren et al., 2002]. Kilbourne et al. [2004] noted the equivalency of these approaches and we use the approach discussed by Gagan et al. [1998] to evaluate seawater $\delta^{18} \mathrm{O} / \mathrm{SSS}$ changes at Rabaul. Evaluation of the calculated seawater $\delta^{18} \mathrm{O}$ record $\left(\Delta \delta^{18} \mathrm{O}\right)$ at Rabaul permits two first observations to be made. First, the coral-based $\Delta \delta^{18} \mathrm{O}$ time series is not significantly correlated with the SSS time series between their common period of overlap (1970-1993; Table 1). Second, coral $\delta^{18} \mathrm{O}$ records, both the monthly and monthly anomaly time series, are highly correlated with the coral-based $\Delta \delta^{18} \mathrm{O}$ time series over the calibration interval $(1970-1993 ; r>0.74)$. The ENSO-filtered version of these records also captures the high-low-high pattern of interannual variability over the 20th century (Figure 9).

[21] The reason for the lack of significant correlation between the calculated seawater $\delta^{18} \mathrm{O}$ and SSS time series cannot be uniquely defined, and may be due to several factors. First, the SSS time series used is not an in situ record of salinity, but rather is extracted from a ship track database that covers $15^{\circ}$ of longitude [Delcroix et al., 2005]. It is possible that local salinity variations at the Rabaul reef site are captured in the coral proxy record, but that these variations deviate significantly from the ship-track data, but we have no way to assess this possibility. Second, SSTs at Rabaul are some of the warmest in the open-ocean and thermal stress factors may be impacting the coral $\mathrm{Sr} / \mathrm{Ca}$ signal [Marshall and McCulloch, 2002]. If true, then the calculated seawater $\delta^{18} \mathrm{O}$ values may be flawed.

[22] The strong correlation between the coral $\delta^{18} \mathrm{O}$ and coral-based $\Delta \delta^{18} \mathrm{O}$ records, both of the calibration interval $(1993-1970 ; r=0.75)$ and over the entire $\sim 130$ year record length $(\mathrm{r}=0.82)$, implies that SST variations play a minor role in driving coral $\delta^{18} \mathrm{O}$ variations at Rabaul. Additional paired coral $\delta^{18} \mathrm{O}$ and $\mathrm{Sr} / \mathrm{Ca}$ time series from other sites in the WPWP are needed to assess whether our findings based on the study of the Rabaul coral are anomalous or whether they also apply to other regions in the WPWP.

\section{Summary and Conclusions}

[23] A $\sim 130$ year record of climate variability in the warmest sector of the WPWP (mean annual SST $>29^{\circ} \mathrm{C}$ ) has been produced based on variations in $\delta^{18} \mathrm{O}$ and $\mathrm{Sr} / \mathrm{Ca}$ measured in a coral from offshore of Rabaul, East New Britain, Papua New Guinea $\left(4^{\circ} \mathrm{S}, 152^{\circ} \mathrm{E}\right)$. Analysis of these proxy climate time series leads to the following conclusions:

[24] 1. Coral $\delta^{18} \mathrm{O}$ and $\mathrm{Sr} / \mathrm{Ca}$ time series are well correlated to each other and positive excursions in both records coincide with times of ENSO warm phase events.

[25] 2. The ENSO-filtered Rabaul coral $\delta^{18} \mathrm{O}$ and $\mathrm{Sr} / \mathrm{Ca}$ time series are well matched to each other and to similarly filtered coral $\delta^{18} \mathrm{O}$ records from eastern Papua New Guinea.

[26] 3. Time varying modulation of the interannual coral $\delta^{18} \mathrm{O}$ and $\mathrm{Sr} / \mathrm{Ca}$ signals display a pattern of low amplitude variation between $\sim 1920-1960$ separating two intervals of high amplitude variation (1880-1920 and 1960-1997). This pattern is consistent with previous observations from proxy and instrumental records.

[27] 4. There is no significant long-term trend in the coral $\delta^{18} \mathrm{O}$ record, but there is a long-term trend of increasing coral $\mathrm{Sr} / \mathrm{Ca}$ from 1867 to 1997 . If interpreted solely as a change in SST, the coral $\mathrm{Sr} / \mathrm{Ca}$ trend would indicate cooling of $\sim 0.7{ }^{\circ} \mathrm{C}$ over this time, which contrasts with most other observations in the region and implies that factors other than SST may be influencing the coral $\mathrm{Sr} / \mathrm{Ca}$ record at Rabaul. Additional coral $\mathrm{Sr} / \mathrm{Ca}$ time series from other sectors of the WPWP are needed to assess whether the long-term trend observed at Rabaul is anomalous or is reflecting true surface-ocean variability.

[28] 5. Despite the presence of a nonclimatic trend in the coral $\mathrm{Sr} / \mathrm{Ca}$, the coral $\mathrm{Sr} / \mathrm{Ca}$ and $\delta^{18} \mathrm{O}$ time series contain abundant interannual- to multidecadal-scale variability, much of which is coherent with other proxy records from the WPWP and with instrumental records of ENSO variability.

[29] Acknowledgments. This research was supported in part by awards from NSF-Earth System History (TMQ, OCE-9727414; FWT, OCE-971054) and NOAA-Paleoclimatology Program (TMQ, NA76GP0505; FWT, NA76GP0268). We thank George Burr and Nicholas Van Wyck for assisting with fieldwork, Hugh Davies of the University of Papua New Guinea for sponsoring the project, Michael Laki of the National Research Institute for arranging permits and inspections, and the Papua New Guinea and East Britain Province governments for permission to conduct fieldwork. We also thank Jennifer Smith, Hali Kilbourne, and Kristine DeLong for reading earlier versions of this manuscript; Kristine DeLong and Jon Eischod for help with the figures; and Ethan Goddard for technical assistance and laboratory management. Quinn is grateful to the Jackson School of Geosciences and the Institute for Geophysics at the University of Texas for their support during his sabbatical leave, during which time this manuscript was written.

\section{References}

Alibert, C., and M. T. McCulloch (1997), Strontium/calcium ratios in modern Porites corals from the Great Barrier Reef as a proxy for sea surface temperature: Calibration of the thermometer and monitoring of ENSO, Paleoceanography, 12, 345-363.

Allison, N., and A. A. Finch (2004), High resolution $\mathrm{Sr} / \mathrm{Ca}$ records in modern Porites lobata corals: Effects of skeletal extension rate and architecture, Geochem. Geophys. Geosyst., 5, Q05001, doi:10.1029/ 2004GC000696.

Allison, N., A. A. Finch, A. W. Tudhope, M. Newville, S. R. Sutton, and R. M. Ellam (2005), Reconstruction of deglacial sea surface temperatures in the tropical Pacific from selective analysis of a fossil coral, Geophys. Res. Lett., 32, L17609, doi:10.1029/2005GL023183.

Beck, J. W., R. L. Edwards, E. Ito, F. W. Taylor, J. Recy, F. Rougerie, P. Joannot, and C. Henin (1992), Sea-surface temperature from coral skeletal $\mathrm{Sr} / \mathrm{Ca}$ ratios, Science, 257, 64-647.

Behringer, D. W., M. Ji, and A. Leetmaa (1998), An improved coupled model for ENSO prediction and implications for ocean initialization. Part I: The ocean data assimilation system, Mon. Weather Rev., 126, $1013-$ 1021 .

Broecker, W. S., and T.-H. Peng (1982), Tracers in the Sea. 691 pp., Lamont-Doherty Geol. Obs., Palisades, N. Y.

Cobb, K. M., C. D. Charles, and D. E. Hunter (2001), A central tropical Pacific coral demonstrates Pacific Indian, and Atlantic decadal climate connections, Geophys. Res. Lett., 28(11), 2209-2212.

Cohen, A. L., K. E. Owens, G. D. Layne, and N. Shimizu (2002), The effect of algal symbionts on the accuracy of $\mathrm{Sr} / \mathrm{Ca}$ paleotemperatures from coral, Science, 296, 331-333.

Cole, J. E., R. G. Fairbanks, and G. T. Shen (1993), The spectrum of recent variability in the Southern Oscillation: Results from a Tarawa Atoll coral, Science, 260, 1790-1793.

Corrège, T. (2006), Sea surface temperature and salinity reconstruction from coral geochemical tracers, Palaeogeog. Palaeoclim. Palaeoecol., 232, 408-428.

DeDeckker, P. (2004), On the celestite-secreting Acantharia and their effect on seawater strontium to calcium ratios, Hydrobiologia, 517, 1-13.

Delcroix, T., M. J. McPhaden, A. Dessier, and Y. Gouriou (2005), Time and space scales for sea surface salinity in the tropical oceans, Deep Sea. Res., $52(5), 787-813$.

DeLong, K. L., T. M. Quinn, and F. W. Taylor (2005), Sea surface temperature variability in the southwest tropical Pacific since 1679 AD derived from coral skeletal geochemistry, Eos Trans. $A G U, 86(52)$, Fall Meet. Suppl., Abstract PP21C-1569. 
de Villiers, S., G. T. Shen, and B. K. Nelson (1994), The Sr/Ca-temperature relationship in coralline aragonite: Influence of variability in $(\mathrm{Sr} / \mathrm{Ca})$ seawater and skeletal growth parameters, Geochim. Cosmochim. Acta, 58, $197-208$

Eisenhauer, A., K. Wyrwoll, L. Collins, Z. Zhu, G. Heiss, and B. Hansen (1999), Sr/Ca- and U/Ca-thermometry of modern and fossil coral from the Abrolhos Islands and the Ningaloo Reef, Western Australia, Eos Trans. $A G U, 80(46)$, Fall Meet. Suppl., Abstract OS52A-18.

Gagan, M. K., L. K. Ayliffe, D. Hopley, J. A. Cali, G. E. Mortimer, J. Chappell, M. T. McCulloch, and M. J. Head (1998), Temperature and surface-ocean water balance of the Mid-Holocene tropical western Pacific, Science, 279, 1014-1018.

Gagan, M. K., L. K. Ayliffe, J. W. Beck, J. E. Cole, E. R. M. Druffel, R. B. Dunbar, and D. P. Schrag (2000), New views of tropical paleoclimates from corals, Quat. Sci. Rev., 19, 45-64.

Guilderson, T. P., and D. P. Schrag (1999), Reliability of coral isotope records from the western Pacific warm pool: A comparison using ageoptimized records, Paleoceanography, 14, 457-464.

Guilderson, T. P., D. P. Schrag, and M. A. Cane (2004), Surface water mixing in the Solomon Sea as documented by a high-resolution coral $14 \mathrm{C}$ record, J. Clim., 17, 1147-1156.

Hart, S. R., and A. L. Cohen (1996), An ion probe study of annual cycles of $\mathrm{Sr} / \mathrm{Ca}$ and other trace elements in corals, Geochim. Cosmochim. Acta, 60, 3075-3084.

Hendy, E. J., M. K. Gagan, C. A. Alibert, M. T. McCulloch, J. M. Lough, and P. J. Isdale (2002), Abrupt decrease in tropical Pacific sea surface salinity at the end of the Little Ice Age, Science, 295, 1511-1514.

Houck, J. E., R. W. Buddemeier, S. V. Smith, and P. L. Jokiel (1977), The response of coral growth rate and skeletal strontium content to light intensity and water temperature, Proc. Third Int. Coral Reef, 425-432.

Kilbourne, K., T. M. Quinn, F. Taylor, T. Delcroix, and Y. Gouriou (2004), ENSO-related salinity variations recorded in the skeletal geochemistry of a Porites coral from Espiritu Santo, Vanuatu, Paleoceanography, 19, PA4002, doi:10.1029/2004PA001033.

Kinsman, D. J. J., and H. D. Holland (1969), The coprecipitation of cations with $\mathrm{CaCO} 3$. IV. The coprecipitation of $\mathrm{Sr} 2+$ with aragonite between 16 and 96 C, Geochim. Cosmochim. Acta, 33, 1-17.

Le Bec, N., A. Juillet-Leclerc, T. Corrège, D. Blamart, and T. Delcroix (2000), A coral $\delta^{18} \mathrm{O}$ record of ENSO driven seas surface salinity variability in Fiji (southwestern tropical Pacific), Geophys. Res. Lett., 27(23), 3897-3900.

Levitus, S., R. Burgett, and T. P. Boyer (1994), World Ocean Atlas 1994, vol. 3, Salinity, NOAA/NESDIS E/OC21, 99 pp., U. S. Dep. of Commer., Washington, D. C

Linsley, B. K., G. M. Wellington, and D. P. Schrag (2000), Decadal sea surface temperature variability in the subtropical South Pacific from 1726 to 1997 A. D., Science, 290, 1145-1148.

Linsley, B. K., G. M. Wellington, D. P. Schrag, L. Ren, M. J. Salinger, and A. W. Tudhope (2004), Geochemical evidence from corals for changes in the amplitude and spatial pattern of South Pacific interdecadal climate variability over the last 300 years, Clim. Dyn., 22, 1-11.

Marshall, J. F., and M. T. McCulloch (2002), An assessment of the Sr/Ca ratio in shallow water hermatypic corals as a proxy for sea surface temperature, Geochim. Cosmochim. Acta, 66, 3263-3280.

McCulloch, M. T., M. K. Gagan, G. E. Mortimer, A. R. Chivas, and P. J. Isdale (1994), A high-resolution $\mathrm{Sr} / \mathrm{Ca}$ and $\delta^{18} \mathrm{O}$ coral record from the Great Barrier Reef, Australia, and the 1982-1983 El Nino, Geochim. Cosmochim. Acta, 58, 2747-2754.

Meibom, A., M. Stage, J. Wooden, B. R. Constantz, R. B. Dunbar, A. Owen, N. Grumet, C. R. Bacon, and C. P. Chamberlain (2003), Monthly strontium/calcium oscillations in symbiotic coral aragonite: Biological effects limiting the precision of the paleotemperature proxy, Geophys. Res. Lett., 30(7), 1418, doi:10.1029/2002GL016864.

Paillard, D., L. Labeyrie, and P. Yiou (1996), Macintosh program performs time-series analysis, Eos Trans. $A G U, 77,379$.

Quinn, T. M., and D. E. Sampson (2002), A multiproxy approach to reconstructing sea surface conditions using coral skeleton geochemistry, Paleoceanography, 17(4), 1062, doi:10.1029/2000PA000528.

Quinn, T. M., and F. W. Taylor (2006), SST artifacts in coral proxy records produced by early marine diagenesis in a modern coral from Rabaul, Papua New Guinea, Geophys. Res. Lett., 33, L04601, doi:10.1029/ 2005GL024972.

Rayner, N. A., D. E. Parker, E. B. Horton, C. K. Folland, L. V. Alexander, D. P. Rowell, E. C. Kent, and A. Kaplan (2003), Global analyses of SST, sea ice, and night marine air temperature since the late nineteenth century, J. Geophys. Res., 108(D14), 4407, doi:10.1029/2002JD002670.

Ren, L., B. K. Linsley, G. M. Wellington, D. P. Schrag, and O. HoeghGuildberg (2002), Deconvolving the $\delta^{18} \mathrm{O}$ seawater component from subseasonal coral $\delta^{18} \mathrm{O}$ and $\mathrm{Sr} / \mathrm{Ca}$ at Rarotonga in the southwestern subtropical Pacific for the period 1726 to 1997, Geochim. Cosmochim. Acta, 67(9), 1609-1621.

Shen, C.-C., T. Lee, C.-Y. Chen, C.-H. Wang, C.-F. Dai, and L.-A. Li (1996), The calibration of $\mathrm{D}[\mathrm{Sr} / \mathrm{Ca}]$ versus sea surface temperature relationship for Porites corals, Geochim. Cosmichim. Acta, 60, 3849-3858.

Smith, S. V., R. W. Buddemeier, R. C. Redalje, and J. E. Houck (1979), Strontium-calcium thermometry in coral skeletons, Science, 204, 404407.

Stephans, C., T. M. Quinn, F. Taylor, and T. Corrège (2004), Assessing the reproducibility of coral-based climate records, Geophys. Res. Lett., 31, L18210, doi:10.1029/2004GL020343.

Torrence, C., and G. P. Compo (1998), A practical guide to wavelet analysis, Bull. Am. Meteorol. Soc., 79, 6178.

Torrence, C., and P. J. Webster (1999), Interdecadal changes in the ENSOMonsoon System, J. Clim., 12, 2679-2690.

Trenberth, K. E. (1997), The definition of El Niño, Bull. Am. Meteorol. Soc., $78(12), 2771-2777$.

Tudhope, A. W., G. B. Shimmield, C. P. Chilcott, M. Jebb, A. E. Fallick, and A. N. Dalgleish (1995), Recent changes in climate in the far western equatorial Pacific and their relationship to the Southern Oscillation; oxygen isotope records from massive corals, Papua New Guinea, Earth Planet. Sci. Lett., 136, 575-590.

Tudhope, A. W., C. P. Chilcott, M. T. McCulloch, E. R. Cook, J. Chappell, R. M. Ellam, D. W. Lea, J. M. Lough, and G. B. Shimmield (2001), Variability in the El Niño-Southern Oscillation through a glacial-interglacial cycle, Science, 291, 1511-1517.

Urban, F. E., J. E. Cole, and J. T. Overpeck (2000), Influence of mean climate change on climate variability from a 155-year tropical Pacific coral record, Nature, 407, 989-993.

Weber, J. N. (1973), Incorporation of strontium into reef skeletal carbonate, Geochim. Cosmochim. Acta, 37, 2173-2190.

T. J. Crowley, Department of Earth and Ocean Sciences, Nicholas School of the Environment and Earth Sciences, Duke University, Durham, NC 27708, USA.

T. M. Quinn, College of Marine Science, University of South Florida, St. Petersburg, FL 33701, USA. (quinn@marine.usf.edu)

F. W. Taylor, Institute for Geophysics, The John A. and Katherine G. Jackson School of Geosciences, University of Texas at Austin, Austin, TX 78759-8500, USA. 